\title{
ASSESSMENT OF THE USAGE OF CONTRACEPTIVE AMONG COLLEGE OF HEALTH SCIENCES STUDENTS OF NIGER DELTA UNIVERSITY, AMASSOMA BAYELSA STATE, NIGERIA
}

\section{Oniso Juliet Imawaigha ${ }^{1}$ and Tawari Erebi Patricia ${ }^{2 *}$}

\author{
${ }^{1}$ Department of Maternal and Child Health Nursing, Faculty of Nursing, College of Health \\ Science, Niger Delta University, Bayelsa State, Nigeria
}

${ }^{2}$ Department of Chemical Pathology, Faculty of Basic Medical Sciences, College of Health Science, Niger Delta University, Bayelsa State, Nigeria

*Corresponding author: perebi8@yahoo.com

Cite this article:

Oniso J.I., Tawari E.P. (2021), Assessment of the Usage of Contraceptive among College of Health Sciences Students of Niger Delta University, Amassoma Bayelsa State, Nigeria. African Journal of Biology and Medical Research 4(3), 49-58. DOI: 10.52589/AJBMRUR6B9QL9.

\section{Manuscript History}

Received: 30 May 2021

Accepted: 25 June 2021

Published: 6 July 2021

Copyright $(92020$ The Author(s). This is an Open Access article distributed under the terms of Creative Commons AttributionNonCommercial-NoDerivatives 4.0 International (CC BY-NC-ND 4.0 ), which permits anyone to share, use, reproduce and redistribute in any medium, provided the original author and source are credited.
ABSTRACT: Background: Contraceptives are the of use artificial devices to prevent pregnancy and sexually transmitted disease such as HIV/STIs. Despite the existence of numerous family planning programmes in recent years, the prevalence rate of contraceptive use remains low in several developing countries. Therefore, this study was conducted to examine the use Contraceptive among students in the College of Health of Health Science, Niger Delta University, Amassoma. Method: A descriptive cross-sectional study design was conducted among two hundred (200) students of the College of Health of Health Science, Niger Delta University aged 16-30 years. Data collection was carried out using both self-administered questionnaire Results: Data showed that majority of the students in College of Health Science, Niger Delta University are about (84\%) sexually experience with most of the first sexual experiences occurring within the 16-20 years' age group. $47 \%$ identified that they discuss contraceptives the first time they had sex while $22.0 \%$ of the respondents revealed that they did not discuss any contraceptives with their partner the first they had sex. $30.5 \%$ sexually active females stated that they have been pregnant and $34.1 \%$ sexually active males had impregnated a girl, (50\%) ended up in abortion while (6.8\%) respondents are currently pregnant. Conclusion: A sizable number of respondents revealed that they did not use any contraceptives the first time they had sex. Therefore, there is a need to improve the awareness and encourage the use of conceptive among youths.

KEYWORDS: Contraceptive, Usage, Student, Amassoma 


\section{INTRODUCTION}

Contraception the use of a contraceptive method to avert pregnancy by disrupting ovulation, fertilization, and/or implantation can be used to aid men/women in planning for the number of children and when to have them (Csapo, et al., 2017). Contraceptive methods can be categorized into modern and traditional methods. Modern contraceptives can be classified as, intrauterine devices (IUDs), oral contraceptives, female and male sterilization, injections, condoms, and the diaphragm (Apter, 2012). Other practices such as prolonged breastfeeding and postpartum sexual abstinence also have a bearing on fertility (WHO, 2017).

Adolescents predominantly prefer using condoms as their main contraceptive. In developing countries, surveys have shown that the highest level of contraceptive use, are among unmarried, sexually active youth between the ages of 20 and 24 years, the lowest levels are among adolescent married women between the ages of 15 and 19 years (WHO, 2015). Consequently, from the survey, few married adolescents use contraception. Previous research revealed that only $13 \%$ of married youth in this age group use contraception, among unmarried, sexually active adolescents in this same age group, the level of contraceptive use reaches $39 \%$ married women and $60 \%$ of unmarried, sexually active women between the ages of 15 and 19 years use contraception (Zlidar, 2013; WHO, 2015). Despite the existence of numerous family planning programmes for more than 40 years, the prevalence rate of contraceptive use remains low in several countries. A contraceptive prevalence rate of $80-85 \%$ is viewed as consistent, optimum and ideal to ensure safe pregnancies and births (Ganchimeg, et al., 2014). As of 2008, the prevalence of contraceptive use was $61.7 \%$ in developing countries with huge variations. Specifically, a rate of $2.8 \%$ in Chad and $80 \%$ in Costa Rica, and $28 \%$ in the African region, has been reported (Ganchimeg et al., 2014).

Generally, contraceptive use has increased worldwide. However, reproductive health service, high-quality comprehensive sexuality education, adolescent access to sexual health service, confidentiality, informed consent and privacy remains a challenge in several countries (Puri \& Cleland, 2015). In developing countries, access to family planning and sex education is poor among adolescents and youths. Studies from Africa have revealed that a high proportion of adolescents are predisposed to conception related risk. This could be attributed to poor or no sex and contraception education accounting for high incidence of childbirth. There is also the tendency of health workers and family to overlook the reproductive needs of adolescent because of cultural and religious value as reported by (Darko, 2016; Tayo, et al., 2011; Trinh, 2012). This study was conducted to assess the usage of contraceptive among students in College of Health Science, Niger Delta University, Bayelsa State.

\section{METHODOLOGY}

\section{Study Area}

The study was conducted at the College of Health Science, Niger Delta University Wilberforce Island, Bayelsa state. The College of Health Science, Niger Delta University is situated in Amassoma, Southern Ijaw Local Government Area, Bayelsa State. Amassoma community consists of 22 compounds. Inhabitants are mainly Izons, other major ethnic groups' resident in the area includes Igbos, Hausas, Yoruba, Urhobos, Ibibios. Majority are Christians and few others in other faiths. Petty traders form the greatest bulk of the population with civil servants, 
farmers, fishermen/women as well as students cohabiting in the community respectively. College of Health Science is a tertiary institution; it is made up of various Faculties and Departments. The College is accessible by land and sea. It is composed of four major departments namely; Nursing, Medicine and Surgery, Medical Laboratory Science and Biochemistry.

\section{Sampling Technique}

The sampling technique used in this study is the simple random sampling technique. This was used to select two hundred (200) respondents out of the target population.

\section{Study Population}

The target population of the study were students of College of Health Science, Niger Delta University.

\section{Instrument for Data Collection}

A self-structured Questionnaire based on the use of contraceptive was randomly disturbed among the target population of students of College of Health Science, Niger Delta University.

\section{Validity of Instrument}

In other to determine the validity of the instrument, the questionnaire was prepared by the researcher and submitted to the supervisors for necessary correction and scrutiny before administered to respondent.

\section{Reliability of Instrument}

In order to warrant the reliability of the instrument a test-retest method was used to test the reliability of the instrument. Their responses will be appraised to ascertain the internal consistency of data gotten from the instrument. Question was reframed for clarity and relevance to the stated research objectives.

\section{Study Duration}

The duration of this study was over a period of 4 weeks, entailing time expended on procurement of approval, data collection, collation, analysis and report writing.

\section{Ethical Consideration}

Ethical approval for the conduct of the study was obtained from the Research and Ethics Committee of College of Health Science, Niger Delta University, before commencement. An informed consent was acquired from the prospective respondent asserting the purpose of the study and assurance of confidentiality. The respondent were made to comprehend that the study was for academic purpose and involvement was voluntary and information provided was treated with utmost privacy. 


\section{RESULTS}

The total of 200 well-structured questionnaires were administered to the Target population. Response rate was $100 \%$. The 200 questionnaires were distributed, collected and analysed. Tables were used to represent the results from the data analysis.

Table 1 showed the Socio-demographics Profile of the respondents. Majority of the respondents were female students $(57.5 \%)$; the male respondents were $(42.5 \%)$ of the sample. The highest proportion of respondents were aged between 16 and 20 years (44.5\%); followed by those aged 21-25 (35.5\%) and then those aged 26-30years (20\%). The table also demonstrated that most of the respondents were single (71.0\%) and married people were $29 \%$. No respondents in the sample was divorce. The distribution of respondents by religious affiliation showed that Christianity $(90 \%)$ was the dominant religion in the study location. This was followed by those who practiced Islamic Religion (10\%). No person found to practice African Traditional Religion.

Table 1: Socio-demographic Characteristics of the Respondents

\begin{tabular}{|ll|c|c|}
\hline \multicolumn{2}{|c|}{ Variable } & Frequency & Percentage \\
\hline Sex & Female & 115 & 57.5 \\
& Male & 85 & 42.5 \\
\hline & Total & $\mathbf{2 0 0}$ & $\mathbf{1 0 0}$ \\
\hline Age & $16-20$ & 71 & 44.5 \\
& $21-25$ & 89 & 35.5 \\
& $26-30$ & 40 & 20 \\
\hline \multirow{2}{*}{ Marital Status } & Total & $\mathbf{2 0 0}$ & $\mathbf{1 0 0}$ \\
& Single & 142 & 71 \\
& Married & 58 & 29 \\
& Divorce & 0 & 0 \\
\hline Religious Affiliation & Total & $\mathbf{2 0 0}$ & $\mathbf{1 0 0}$ \\
& Christian & 180 & 90 \\
& Muslim & 20 & 10 \\
& Traditionalist & 0 & 0 \\
\hline \multicolumn{2}{c}{} & $\mathbf{2 0 0}$ & $\mathbf{1 0 0}$ \\
\hline
\end{tabular}

Table 2 showed that the three most frequently spontaneously named contraceptive methods the respondents indicated they know were condom, withdrawal, safe periods and pills $(50 \%, 39 \%$, and $19.5 \%$ respectively. This was followed by Injectable and pills method that students in College of Health Science, Niger Delta University have more knowledge of condoms, withdrawal and safe periods as a contraceptive method than any other methods 
Table 2: Distribution of Respondents by type of Contraceptive Methods they know

\begin{tabular}{|l|c|c|}
\hline Contraceptive methods & Frequency & Percentage \\
\hline Condom & 100 & 50 \\
\hline Pills & 27 & 13.5 \\
\hline Injectable & 12 & 6 \\
\hline Withdrawal & 78 & 39 \\
\hline Safe period & 39 & 19.5 \\
\hline Total & $\mathbf{2 0 0}$ & $\mathbf{1 0 0}$ \\
\hline
\end{tabular}

Table 3 revealed that one hundred and twenty three (123) respondents approved use of contraceptives by students and seventy seven (77) respondents disapprove the use of contraceptive. Reason most of the students gave was that their parents disapprove use of contraceptives, they also stated that their societies disapprove involvement of youth in sexual activity and sees it as evil and dangers for success.

Table 3: Distribution of Respondents on if they approve use of Contraceptive Methods by Student.

\begin{tabular}{|l|c|c|}
\hline Approve use of contraceptive & Frequency & Percentage \\
\hline Yes & 123 & 61.5 \\
\hline No & 77 & 38.5 \\
\hline Total & $\mathbf{2 0 0}$ & $\mathbf{1 0 0}$ \\
\hline
\end{tabular}

Table 4 shows that 46.5 percent think male partners should practice contraceptives. Similarly, 45 percent think female partner should be responsible to practice contraceptives. However, 8.5 percent of the respondents said both.

Table 4: Distribution of Respondents by who they think should take responsibility to practice Contraceptives.

\begin{tabular}{|l|c|l|}
\hline Who should practice contraceptive & Frequency N=200 & Percentage100\% \\
\hline Female & 90 & 45 \\
\hline Male & 93 & 46.5 \\
\hline Both & 17 & 8.5 \\
\hline
\end{tabular}

\section{Sexual History}

Table 5, showed that $(58.5 \%)$ of the total population have sexual partner. While $(48.5 \%)$ indicate that they don't have sexual partner. With the high percentage of respondents who have sexual partner, it shows that sexual activities are quite high among students in College of Health Science, Niger Delta University. 
Table 5: Percentage distribution of Respondents on if they have sexual partner

\begin{tabular}{|l|l|l|}
\hline Do you have sexual partner? & Frequency N=200 & Percentage100\% \\
\hline Yes & 103 & 51.5 \\
\hline No & 97 & 48.5 \\
\hline
\end{tabular}

Table 6, shows that the majority of the respondents 84.0 percent have had sex, followed by 13.5 percent respondents who reported they have never had sex, while 2.5 percent declined to respond to the question.

Table 6 Distribution of Respondents by if they have ever had sexual intercourse

\begin{tabular}{|l|l|l|}
\hline Have you ever have sexual intercourse & $\begin{array}{l}\text { Frequency } \\
\text { N=200 }\end{array}$ & $\begin{array}{l}\text { Percentage } \\
100 \%\end{array}$ \\
\hline Yes & 168 & 84 \\
\hline No & 27 & 13.5 \\
\hline No response & 5 & 2.5 \\
\hline
\end{tabular}

Figure 1 revealed that the majority of the respondents had sex for the first time between the ages of 16-20 years. This was followed by those respondents between the ages of 10-15 years. From the figure it was obvious that respondents between the ages of 21-25 years had sexual intercourse for the first time compared with respondents who admitted they had sex for the first time from 25 years and above. From the study, it was observed that as age increases, sexual activities also increase among youth.

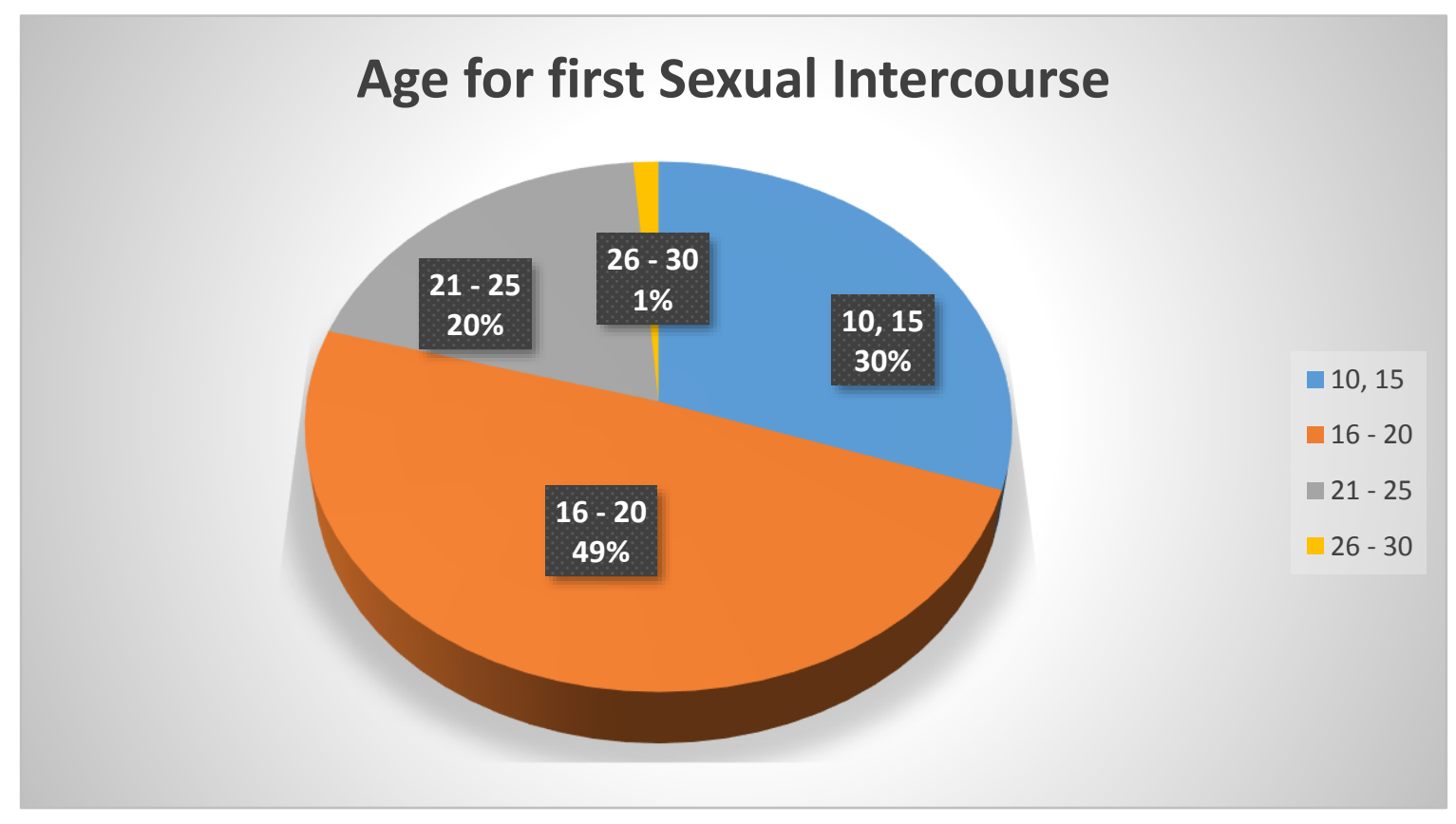

Figure 1: Distribution of Respondents by how old they were the first time they had sex 
African Journal of Biology and Medical Research

ISSN: 2689-534X

Volume 4, Issue 3, 2021 (pp. 49-58)

www.abjournals.org

Table 7 shows that out of the 200 hundred sampled population, 95 agreed to have used contraceptives, 40 disagree while 25 respondents did not indicate. Some of the respondents stated that they took the contraceptive for medical reason.

Table 7: Distribution of Respondents on if they ever used Contraceptive during their last sexual intercourse

\begin{tabular}{|l|l|l|}
\hline $\begin{array}{l}\text { Have you ever used Contraceptive during their last } \\
\text { sexual intercourse? }\end{array}$ & $\begin{array}{l}\text { Frequency } \\
\text { N=200 }\end{array}$ & $\begin{array}{l}\text { Percentage } \\
100 \%\end{array}$ \\
\hline Yes & 95 & 47.5 \\
\hline No & 40 & 20 \\
\hline No response & 25 & 12.5 \\
\hline
\end{tabular}

Table 8 showed that the majority of the respondents 47 percent identified that they discuss contraceptives the first time they had sex while 22.0 percent of the respondents identified that they did not discuss any contraceptives with their partner the first they had sex. However, 17.5 percent stated that they do not remember. Twenty seven (27) of the respondents did not respond to the question.

Table 8: Distribution of Respondents on if they discuss Contraceptive methods with their partner the first time they had sex.

\begin{tabular}{|l|l|l|}
\hline $\begin{array}{l}\text { Did you discuss contraceptive method with your } \\
\text { partner }\end{array}$ & $\begin{array}{l}\text { Frequency } \\
\text { N=200 }\end{array}$ & $\begin{array}{l}\text { Percentage } \\
100 \%\end{array}$ \\
\hline Yes & 94 & 47 \\
\hline No & 44 & 22 \\
\hline Don't remember & 35 & 17.5 \\
\hline No response & 27 & 13.5 \\
\hline
\end{tabular}

Table 9 revealed that high majority of the respondent $(48.5 \%)$ did respond if they used contraceptive the first time they had sex. Meanwhile, 29 percent of the respondent reported they did not use a contraceptive method. On the other hand, 22.5 percent not indicate if they used any contraceptives method or not.

Table 9: Percentage distribution of respondents by if they use contraceptives the first time they had sex

\begin{tabular}{|l|l|l|}
\hline $\begin{array}{l}\text { Did you discuss contraceptive method with your } \\
\text { partner }\end{array}$ & $\begin{array}{l}\text { Frequency } \\
\text { N=200 }\end{array}$ & $\begin{array}{l}\text { Percentage } \\
100 \%\end{array}$ \\
\hline Yes & 97 & 48.5 \\
\hline No & 58 & 29 \\
\hline No response & 45 & 22.5 \\
\hline
\end{tabular}

Table 10 indicated that out of the one hundred and fifteen (115) sexually active female respondents' who responded to question that asked whether they had been pregnant, $(30.0 \%)$ of the total population admitted they had been pregnant while $(57.3 \%)$ admitted they never been pregnant. However, 12.2 percent declined to respond to the question. 
African Journal of Biology and Medical Research

ISSN: 2689-534X

Volume 4, Issue 3, 2021 (pp. 49-58)

www.abjournals.org

Table 10: Distribution of Female Respondents by if they have ever been pregnant

\begin{tabular}{|l|l|l|}
\hline Have you ever have ever been pregnant & $\begin{array}{l}\text { Frequency } \\
\text { N=115 }\end{array}$ & $\begin{array}{l}\text { Percentage } \\
100 \%\end{array}$ \\
\hline Yes & 35 & 30.5 \\
\hline No & 66 & 57.3 \\
\hline No response & 14 & 12.2 \\
\hline
\end{tabular}

Table 11 showed that out of the eighty five (85) sexually active male respondents, twenty nine (29) admitted they have impregnated a girl while forty (40) identified that they have not. Sixteen (16) respondents declined to respond to the question.

Table 11: Distribution of male respondents by if they have impregnated a girl

\begin{tabular}{|l|l|l|}
\hline Have you ever impregnated a girl & $\begin{array}{l}\text { Frequency } \\
\mathrm{N}=85\end{array}$ & $\begin{array}{l}\text { Percentage } \\
100 \%\end{array}$ \\
\hline Yes & 29 & 34.1 \\
\hline No & 40 & 47.1 \\
\hline No response & 16 & 18.8 \\
\hline
\end{tabular}

\section{Outcome of pregnancy}

The important issue here was that since about 30.5 percent of the female respondents admitted that they have been pregnant and 34.1 percent male respondents admitted they have impregnated a girl, it is now necessary to know the outcome of the pregnancies.

Figure 2 shows that out of 35 sexually active females who have been pregnant and 29 sexually active males who have impregnated a girl, (50\%) ended up in abortion while $(6.8 \%)$ respondents are currently pregnant. However, 9.2 percent have given birth, $(14.7 \%)$ responded to live birth and abortion and seventeen (17) respondents did not indicate any outcome.

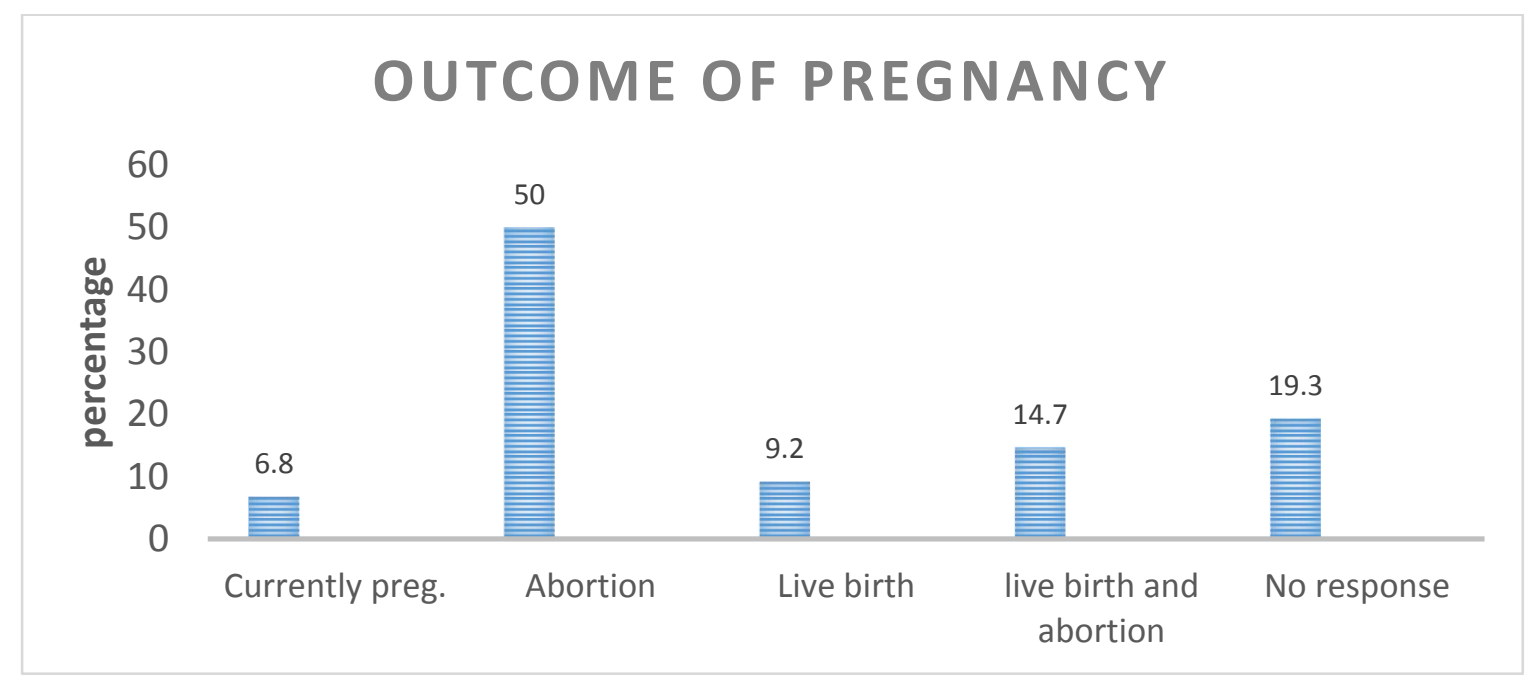

Figure 2: Distribution of Respondents on the outcome of the Pregnancy 


\section{DISCUSSION}

Most adolescents in sub-Sahara Africa are not provided with adequate advice and education on reproductive health issues. Nevertheless, population growth and rapid urbanization have forced most African countries to invest in family planning intervention (Asiimwe, et al., 2013). Contraception refers to the use of artificial methods/techniques to prevent pregnancy through temporal or permanent means. Pernoll (2014) stated that contraception is practiced for many reasons, such as pregnancy planning, limiting the number of children, avoiding medical risks of pregnancy and controlling of world population.

From the study many of the students had knowledge and are aware of contraception, and many were found to have been able to explain what contraceptives are meant for, and have cited contraceptives as methods or drugs used by women or men to prevent unplanned/unwanted pregnancies and spacing of children for their desired families as well as prevention against of sexually transmitted diseases such as HIV/AIDS, gonorrhoea, syphilis and among others. Data from this study revealed that $51.5 \%$ of respondents were sexually active or have sexual partner which indicated that sexual activity is quite high among students in College of Health Science, Niger Delta University. Majority of the respondents 84.0 percent have had sex, followed by 13.5 percent respondents who reported they have never had sex, while 2.5 percent declined to respond to the question. Consequently, the mean age at the sexual debut was $0.57 .5 \%$ for females and $0.42 .5 \%$ for males. Moreso, from this study $30.5 \%$ have been pregnant in which $50 \%$ resulted in abortion. This indicates that females are at higher risk facing consequences of youth sexuality than their male counterparts. This study agreed with the study of (Nyarko, 2015) who stated that Female adolescents who do not practice safe sex but are sexually active stand the risk of unintended pregnancies. Unplanned pregnancies tend to be associated with other health complications such as miscarriages, unsafe abortions and stillbirths which may result in infant or maternal deaths.

Engagements in sexual activity for the first time in this study are quite lower among students between the ages of 25 years and above. Majority of the respondents (47.5\%) identified that they have used any contraceptives during their last sexual exercise/intercourse. While the lowest proportion $(20.0 \%)$ identified that they have not used contraceptive methods at their last sexual intercourse. Condoms were used by $47.4 \%$ of all the respondents at their last intercourse. This corresponds with the findings of (Boamah et al., 2014) who cited condoms as the most common contraceptive used; which is also true for a study conducted in Kintampo. He also stated that $86.6 \%$ of female adolescents had knowledge of at least one method of contraceptive.

This study demonstrated that majority of the respondents who have ever used contraceptives and inconsistent users might reflect the presence of problems that youth face when trying to use contraceptives. The study shows that youth aged $16-20$ years were less likely to use contraceptives than those aged 21 years and above. And again youth who discuss contraceptives with their friends in this study were (48.5\%) and those that approve use of contraceptives by youth were more likely to use contraceptives without considering the barriers they may face. This was equally reported in the study of (Boamah et al, 2014) which showed a significant relationship between consistent contraceptive use and discussions of contraceptive use among adolescents. It found that about $22 \%$ of adolescents consistently used contraceptives and amongst them those who discussed contraceptive use before their first sexual encounter were more likely to use contraceptives consistently compared to those who had never had any discussion. This explains why youth at their early stages should be provided information and 
guidance. It could also indicate the importance of teachers/parents in providing information about contraceptive use and clearing the negative rumours about contraceptives.

\section{CONCLUSION AND RECOMMENDATION}

A significant number of respondents revealed that they did not use any contraceptives the first time they had sex. Sexual encountered resulted in pregnancy where most of the times were aborted. Therefore, there is need to empower youth in order to expose them to the opportunity for improved access to information on contraceptive use. Given them the basic information will equally help in addressing their fear of side effects of contraceptives.

\section{REFERENCES}

Apter, D. (2012). Adolescent contraception. In Pediatric and Adolescent Gynecology (Vol. 22, pp. 287-301). Karger Publishers.

Asiimwe, J. B., Ndugga, P., \& Mushomi, J. (2013). Socio-demographic factors associated with contraceptive use among young women in comparision with older women in Uganda.

Boamah, EA, Asante KP, Mahama E, Manu G, Ayipah E, Adeniji E, Owusu-Agyei S (2014). Use of contraceptive among adolescents in Kintampo, Ghana: A cross-sectional Study. Open Access Journal of contraceptive Volume 6 Pages 7-15.

Csapo, E., Goette, H. R., Green, J. R., In, C., Eidinow, E., Kindt, J., \& Osborne, R. (2017). Publications for Eric Csapo.

Darko, J. A. (2016). Reproductive and child health: contraceptive knowledge, use and factors affecting contraceptive use among female adolescents (15-19 years) in Ghana.

Ganchimeg. T., Ota, E., Morisaki, N., Laopaiboon, M., Lumbiganon, P., Zhang ., Tuncalp, O. (2014). Pregnacy and Childbirth Outcome among adolescent mothers: a World Health Organization multicountry study. BJOG: An International Journal of Obstetrics and Gynaecology, 121(s1), 40-48.

Pernoll, M. L. (2014). Contraceptive choice among married women in Ghizhou province: socio-cultural and relationship factors. Retrieved 25th January 2020 from http://www.eprints.usm.my/103941/contraceptive us

Puri, M., \& Cleland, J. (2015). Sexual behavior and perceived risk of HIV/AIDS among young migrant factory workers in Nepal. Journal of Adolescent Health, 38(3), 237-246

Tayo, A., Akinola, O., Babatunde, A., Adewunmi, A., Osinusi, D., \& Shittu, L. (2011). Contraceptive knowledge and usage amongst female secondary school students in Lagos, Southwest Nigeria. Journal of Public health and Epidemiology, 3(1), 3437.

Trinh, L. T. T. (2012). Abortions amongst Asian Women in New Zealand: What Do We Know? , University of Otago.

WHO (2015). Make every mother and child count. Retrieved 8th February. 2020 from www.paho.org/English/DD/PRB/whd tool/kit.pdf

WHO (2017). Making pregnancy safer, meeting of women parliamentarians report: Maternal and newborn health and survival. Retrieved 29th January. 2020 from http://www.who.int/making pregnancy/factsfile/women/en/index.html.

Zlidar, V. (2013). New survey findings. The reproductive revolution continues. Population reports. Series m: Special Topics. Spring, 17, 1-42. 